\title{
(a)
}

\section{Correction to: Memory, Amnesia, and Forgetting: Graphic Representations of a Chronic Disease in Twentieth- and Twenty-First-Century Spain}

\author{
Fernando Simón Abad
}

\section{Correction to:}

Chapter 3 in: C. McKinney, D. F. Richter (eds.), Spanish Graphic Narratives, Palgrave Studies in Comics and Graphic Novels, https://doi.org/10.1007/978-3-030-56820-7_3

The book was inadvertently published with a couple of errors:

1. The last name of one of the contributors appears incorrectly. It appears as: Abad, Fernando Simón but should appear as: Fernando, Simón Abad. 2. The same should be corrected on the source line of the opening page of chapter 3: appears as F.S. Abad but must appear as F. Simón Abad.

The updated version of the chapter can be found at https://doi.org/10.1007/978-3-030-56820-7_3

(C) The Author(s) 2021

C. McKinney, D. F. Richter (eds.), Spanish Graphic Narratives, Palgrave Studies in Comics and Graphic Novels, https://doi.org/10.1007/978-3-030-56820-7_14 